\title{
Response of Two Semiarid Grasslands to a Second Fire Application
}

\author{
Carleton S. White, ${ }^{1}$ Rosemary L. Pendleton, ${ }^{2}$ and Burton K. Pendleton ${ }^{2}$ \\ Authors are ${ }^{1}$ Research Associate Professor, Biology Department, University of New Mexico, \\ Albuquerque, NM 87131-0001; and ${ }^{2}$ Research Ecologists, USDA Forest Service, \\ Rocky Mountain Research Station, 333 Broadway SE Suite 115, Albuquerque, NM 87102-3497.
}

\begin{abstract}
Prescribed fire was used in two semiarid grasslands to reduce shrub cover, promote grass production, and reduce erosional loss that represents a potential non-point-source of sediment to degrade water quality. This study measured transported soil sediment, dynamics in soil surface microtopography, cover of the woody shrub, grass, and bare ground cover classes, and soil fertility measured by nitrogen-mineralization potentials for the respective cover classes over a 9-year period during which 2 fires occurred. In general, the effects of two drought periods were equal to or greater than the effects of fire on the measured parameters. Following the second fire at the grama grass-dominated site, the number of live junipers was significantly lowered $(P<0.001)$. Fire consumed grass and shrub cover, which created the potential for greater transport of sediment and loss in soil surface elevation. Soil fertility under shrubs was significantly higher than soil fertility under grasses in both grassland sites before and after the first fire; however, that highly significant pattern was not present after the second fire for about 2 years at both sites. This suggests that the reestablishment of a natural fire frequency would likely dampen the well-documented pattern of greater soil fertility under shrub islands relative to grass islands. Repeat use of prescribed fire may keep shrub cover in check and promote fundamental changes in soil processes within semiarid grasslands, but its value must be weighed against the increased potential for erosion following fire.
\end{abstract}

\begin{abstract}
Resumen
El fuego prescrito se uso en dos pastizales semiáridos para reducir la cobertura de arbustos, promover la producción de zacates y reducir las perdidas de suelo por erosión, la cual representa una fuente potencial no puntual de sedimentos para degradar la calidad del agua. Este estudio midió el sedimento de suelo transportado, las dinámicas en la microtopografía de la superficie del suelo, las clases de cobertura de arbustos leñosos, zacates y suelo desnudo y la fertilidad del suelo, medida por los potenciales de mineralización del nitrógeno para las respectivas clases de cobertura. Las mediciones se realizaron por un periodo de nueve años, durante el cual ocurrieron dos fuegos. En general, los efectos de dos periodos de sequía fueron iguales o mayores que los efectos del fuego en los parámetros medidos. Después del segundo fuego, en el sitio dominado por "Grama grass", el número de "Junipers" vivos fue reducido significativamente $(P<0.001)$. El fuego consumió la cobertura de zacates y arbustos, creando un mayor potencial de transporte de sedimentos y perdidas en la elevación de la superficie del suelo. La fertilidad bajo los arbustos fue significativamente mayor que la fertilidad del suelo bajo los zacates, esto se detectó en ambos sitios de pastizal, antes y después del primer fuego. Sin embargo, ese patrón tan significativo no se presentó después del segundo fuego en ninguno de los dos sitios por aproximadamente dos años. Esto sugiere que el reestablecimiento de la frecuencia del fuego natural probablemente debilitaría el patrón bien documentado de mayor fertilidad del suelo bajo las islas de arbustos que bajo las islas de zacates. El uso repetido del fuego prescrito puede mantener a raya la cobertura de arbustos y promover cambios fundamentales en los procesos del suelo del los pastizales semiáridos, pero su valor debe ser ponderado contra el aumento del potencial de erosión después del fuego.
\end{abstract}

Key Words: shrub control, prescribed fire, wildfire, vegetation cover, soil mineralizable N, islands of fertility, soil erosion bridge, drought

\section{INTRODUCTION}

Sediment from rangelands constitutes the second leading cause of stream impairment by non-point-source pollutants in the state of New Mexico (NMWQCC 1994). Sediment contributes to nutrient loading and to degradation of water resources, but it

Research was funded by the USDA Forest Service, Rocky Mountain Research Station, by a grant from the Cibola National Forest, and by the National Science Foundation through a grant to the Sevilleta LTER Program.

Correspondence: Carl White, Biology Dept, MSC03 2020, University of New Mexico, Albuquerque, NM 87131-0001. Email: cswhite@sevilleta.unm.edu

Manuscript received 16 November 2004; manuscript accepted 15 October 2005. also represents the erosion of soil nutrients and loss of potential productivity from rangelands. During the last century, shrubs and trees have invaded rangelands in the southwest United States following periods of intensive grazing coupled with periods of drought (Buffington and Herbel 1965; Grover and Musick 1990; Frederickson et al. 1998). Erosion and nutrient loss from areas with recent shrub invasion is higher than from associated grasslands (Schlesinger et al. 1999). Thus, restoration of grasslands and the associated reduction of woody species may significantly reduce sediment transport and retain grassland productivity.

Widespread fires at 5- to 10 -year intervals probably maintained the semiarid grasslands of the pre-1900s Southwest 
(Mitchell 1978; Wright 1980; Cook 1995; Gottfried et al. 1995). However, intense grazing that interrupted fuel continuity and direct fire suppression resulted in the near absence of fire and created optimal conditions for woody perennials to invade grasslands (Wright 1980; Briggs and Gibson 1992). Returning fire to these grasslands may restore essential ecosystem functions and slow or reverse the encroachment of woody perennials. Accordingly, prescribed fire is a tool being used by land managers to restore grasslands in this region.

Restoration of grasslands may reduce erosion and nonpoint-source pollution; however, management with fire may present short-term potential for increased erosion and sedimentation. Erosion in the Southwest is episodic in nature, with most soil movement occurring after large, intense storms (Wilcox 1994; DeBano et al. 1998). Erosion is initiated by raindrop impaction, which breaks down soil aggregates and suspends clays in surface waters (Brooks et al. 1991). Vegetation cover intercepts raindrops, protects soil aggregates from raindrop impact, and reduces erosion. As modeled by soil-loss equations (Brooks et al. 1991), an increase in vegetation cover through restoration should result in less erosion, if all other site characteristics are unchanged. However, fire consumes vegetation cover and increases bare soil that is then very susceptible to movement, as evidenced by erosion from a southern Arizona grassland persisting for 2 years following a late-season prescribed burn (O’Dea and Guertin 2003). Managers need to understand the duration and magnitude of potential erosional loss to best use their available management tools.

White and Loftin (2000) reported on the effects of the first application of prescribed fires on sediment transport, changes in soil surface elevations, vegetation cover, and potential soil fertility at two grassland sites in New Mexico. Although the fires reduced vegetation cover, fire was not the major factor controlling erosional loss. Rather, a strong drought period during the first year and a half of the 3-year study was the major factor accounting for changes in the measured characteristics. Additional fire treatments were proposed as part of the on-going restoration effort. Cumulative effects of additional fire treatments were expected with a significant reduction in woody perennials and an increase in grass cover as the desired result.

Each of the 2 grasslands reported by White and Loftin (2000) have experienced 1 additional fire; another cool-season prescribed fire at one site and a warm-season wildfire at the other. The original objective of this research was to document the effects of multiple cool-season fires in 2 semiarid grasslands on vegetation cover type (grass, shrub, or bare ground), potentially mineralizable $\mathrm{N}$ (as a measure of site fertility), and soil erosion or building processes. The original hypothesized patterns included: 1) after an initial consumption of vegetation cover by fire, grasses should respond with regrowth more rapidly than shrubs and achieve greater cover relative to shrubs; 2) the amount of mineralizable $\mathrm{N}$ should increase after fire, but mineralizable $\mathrm{N}$ should return to that of control or unburned soils following regrowth of vegetation; and 3) highintensity precipitation could increase erosion following burning until the vegetation cover recovers and potential for erosion would decline. This article presents the 9-year results of the first 2 fires in what was expected to be the repeated use of coolseason prescribed fire to reduce cover of perennial woody species and reduce soil erosion in semiarid grasslands in central
New Mexico. Measurements continued at the site that experienced the warm-season wildfire although the original objectives had been compromised at that site.

\section{METHODS}

\section{Site Description}

The research is being conducted at 2 study sites that had long histories of heavy grazing near the city of Albuquerque, New Mexico. The Bernalillo Watershed site is a plains-mesa grassland/desert grassland ecotone (Brown 1982) at an elevation of $1660 \mathrm{~m}$, with clayey loam soil, and lies north of the city within the Cibola National Forest. Sheep and cattle grazing ceased in 1947, except for a few trespass cows. The site experienced extensive flooding and erosion that lead to the construction of steep-slope terraces, furrow plowing, pitting, check dams, and grass reseeding beginning in 1953. The second site, the West Mesa, is a Great Basin desert scrub/desert grassland ecotone (Brown 1982) at an elevation of $1820 \mathrm{~m}$, with fine sandy loam soils, and lies west of the city. After cattle grazing ceased in the early 1970 s, surface disturbance at the West Mesa included temporary roads for power-line construction and use by off-road vehicles.

Perennial grasses on the Bernalillo Watershed were black, blue, and sideoats grama (Bouteloua eriopoda [Torr.] Torr., $B$. gracilis [Willd. ex Kunth] Lag. ex Griffiths, and $B$. curtipendula [Michx.] Torr., respectively), purple threeawn (Aristida purpurea Nutt.), galleta (Pleuraphis jamesii Torr.), and dropseed (Sporobolus sp.). Perennial grasses on the West Mesa were Indian ricegrass (Achnatherum hymenoides [Roem $\&$ Schult.] Barkworth), needle-and-thread grass (Hesperostipa comata [Trin. \& Rupr.] Barkworth), purple threeawn, galleta, black grama, and dropseed. Broom snakeweed (Gutierrezia sarothrae [Pursh] Britt. \& Rusby) was the dominant woody perennial at both sites. Other woody perennials included fourwing saltbush (Atriplex canescens [Pursh] Nutt.), winterfat (Krascheninnikovia [Ceratoides] lanata [Pursh] Guldenstaedt), sand sage (Artemisia filifolia Torr.), and one-seed juniper (Juniperus monosperma [Engelm.] Sarg.).

Annual precipitation for both sites averages about $250 \mathrm{~mm}$. The study period, from 1995 through 2003, was one of extremes in precipitation, with both extremely dry and wet periods. This variation is depicted in the graph of the Palmer drought index (PDI; Palmer 1965) values for this region of New Mexico (Fig. 1). The region had only a few months of normal conditions, with most of the period considerably above or below average. The normal growing period for this region is from March through September.

\section{Experimental Design}

Each site includes 4 replicate pairs of control and burned plots, with the burned plot randomly selected within each pair. At the Bernalillo Watershed site, the plots were on 2 mesa tops; 1 pair (1 treatment, 1 control) on a mesa about $400 \mathrm{~m}$ away from the mesa with the other 3 pairs. Fire accidentally entered 1 of the 3 control plots on the same mesa during the prescribed fire in 1998, leaving only 3 control plots for the rest of the study. The 4 pairs at the West Mesa were aligned along an approximate contour beneath a low ridge. At both sites, each plot is 1 ha 
(100 $\mathrm{m}$ on a side), with at least $30 \mathrm{~m}$ separating the plots. Soil and vegetation sampling occurred within the middle $60-\mathrm{m}$ by 60-m area within each plot to protect against edge effects. Within each plot, 3 permanently marked $60-\mathrm{m}$ lines were used for vegetation cover and density measurements (White and Loftin 2000). Soils were collected by cover type (shrub, grass, or bare soil) along the $60-\mathrm{m}$ lines. In the Bernalillo Watershed, each plot had two $3 \times 10$-m runoff-erosion collectors (described below) with only 1 per plot at the West Mesa because of concern for archeological resources.

\section{Prescribed and Wild Fires}

The Bernalillo Watershed was treated with prescribed fire on 2 occasions. All plots, burned and control, were within the 170-ha area slated for burning; therefore, the perimeters of the control plots were protected by fire-retardant foam. The first fire occurred on 15 November 1995. Weather conditions were favorable for prescribed burning with seasonably warm temperatures (about $\left.13^{\circ} \mathrm{C}\right)$, moderate relative humidity $(20 \%-30 \%)$, and light winds $\left(0-4.5 \mathrm{~m} \cdot \mathrm{s}^{-1}\right)$ from the WNW in the morning, shifting to light with gusts $\left(4.5 \mathrm{~m} \cdot \mathrm{s}^{-1}\right.$, gusts to $\left.9 \mathrm{~m} \cdot \mathrm{s}^{-1}\right)$ from the SW in the afternoon. Lines of fire were set with drip torches at about $10-\mathrm{m}$ intervals across the area. The fuels were discontinuous, which resulted in patchy coverage. The following morning, fire was set to large individual unburned patches, which were mostly outside the research plots. The second fire occurred on 28 January 1998 . During the burn, temperatures rose to a maximum of $13.5^{\circ} \mathrm{C}$, relative humidity started at $28 \%$ and fell to around $15 \%$, and winds began light $\left(<4.5 \mathrm{~m} \cdot \mathrm{s}^{-1}\right)$ and rose to a fairly steady $4.5 \mathrm{~m} \cdot \mathrm{s}^{-1}$ from the southwest. The same ignition procedures used in 1996 were followed. Rates of spread for both fires were slow, with average flame lengths of about $0.25 \mathrm{~m}$.

The West Mesa was treated with prescribed fire 14 February 1996. At this site, only the treatment plots were burned. Weather conditions were favorable for prescribed burning, with warm temperatures for the season $\left(13-14^{\circ} \mathrm{C}\right)$, moderate relative humidity $(17 \%-25 \%)$, and light but steady winds $\left(3 \mathrm{~m} \cdot \mathrm{s}^{-1}\right)$ from the WSW. Fuels were fairly continuous at this site and the grasses were of taller stature, which allowed for nearly complete burn coverage. The burn plots were blacklined on the downwind sides and then lit across the windward side. The fire moved with the wind across the entire plot. Rate of spread was moderate $\left(0.1-0.3 \mathrm{~m} \cdot \mathrm{s}^{-1}\right)$, with average flame length of about $0.5 \mathrm{~m}$.

A second fire occurred on the West Mesa as a wildfire on 13 July 2001, apparently caused by lightning at about 1300 hours. A weather station approximately $5 \mathrm{~km}$ away recorded winds from the east to southeast at a minimum speed of about $4.5 \mathrm{~m} \cdot \mathrm{s}^{-1}$, with gusts to $13.5 \mathrm{~m} \cdot \mathrm{s}^{-1}$, and air temperature of about $31^{\circ} \mathrm{C}$. Thus, expected flame lengths and rate of spread would be greater than with the cool-season prescribed fire. The wildfire occurred over all plots; thus, the control plots became once-burned plots and the treatment plots became twiceburned plots in 2001. The site was not actively monitored during the previous year due to lack of funding; however, sampling resumed in the fall of 2001.

\section{Vegetation Cover Analysis}

Aboveground cover of individual plant species, as well as nonvegetation ground cover by categories (bare soil, litter,

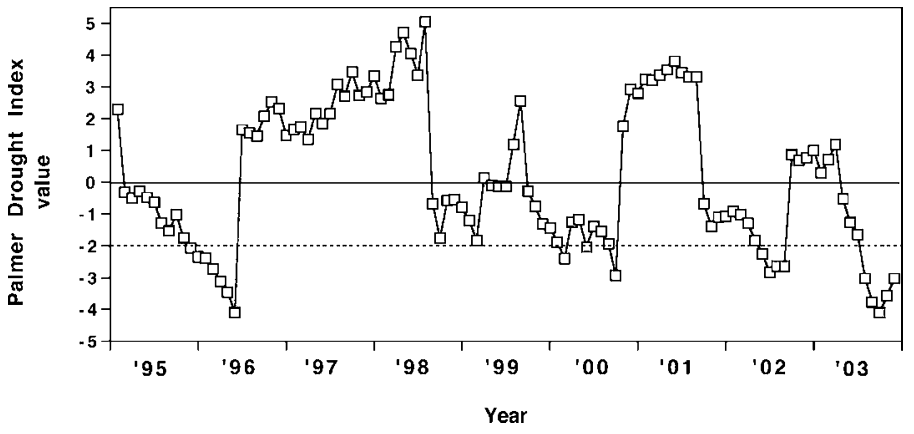

Figure 1. Monthly values for the Palmer drought index (PDI) for New Mexico Region 05, which includes both study sites, from 1995 through 2003. Positive values indicate wetter than normal periods, zero is normal, and negative values are drier than normal, with true drought at or below -2 .

gravel, and rock), were measured using the Community Structure Analysis technique (CSA; Pase 1981) from 1995 through 1998. Percentage cover by species was estimated on a 5 - by $10-\mathrm{cm}$ grid at $1-\mathrm{m}$ intervals along each of the three $60-\mathrm{m}$ vegetation transects (a total of 180 cover samples per plot). Cover by grass or shrub was determined by summing the respective species' cover. In 1999 and 2000, percentage cover was estimated by life form (grass or woody perennial shrub). Sampling on a per-species basis resumed in November of 2001 and continued through October of 2003. In 2001, vegetation was sampled using both the CSA and a modified $1 / 4-\mathrm{m}^{2}$ nested frequency frame (USDA 1982) with 8 points for determining cover. Regression analysis relating cover values of the 2 methods gave adjusted $r$-square values of 0.983 for West Mesa and 0.976 for Bernalillo Watershed. Cover data collected in 2002 and 2003 using the point-frame method were adjusted using equations obtained from the 2001 regression analyses. Plant cover estimates were made before and after each prescribed fire and annually at the end of the growing season or during the winter.

Woody Perennial Inventory. Although junipers were common within the Bernalillo Watershed, only a few actually intercepted the permanent transects within each plot. Thus, to better address the effectiveness of the treatments on junipers, the entire area of each plot on the Bernalillo Watershed was inventoried in February of 2001 for juniper seedlings and established trees. All living and dead plants occurring within the 1-ha plots were measured for height and crown diameters (to the nearest $\mathrm{dm}$ ) and their location mapped using a Garmin GPS 12XL unit. Junipers were less abundant on the West Mesa and were not inventoried.

\section{Sediment Transport}

Runoff-sediment collectors, designed after those used by the Water Erosion Prediction Project (USDA, Purdue University, West Lafayette, IN), measured 3 by $10 \mathrm{~m}$. Two collectors per plot were installed at the Bernalillo Watershed, but only 1 collector per plot on the West Mesa due to archeological restrictions. Average maximum change in elevation across the collectors was $1.18 \mathrm{~m}$ at the Bernalillo Watershed and $1.12 \mathrm{~m}$ at the West Mesa, representative of the average slopes, and was 
Table 1. Mean number of junipers and size of live junipers occurring on burned and unburned plots in the Bernalillo Watershed. Within a column, means with different letters are significantly different (probability value listed below).

\begin{tabular}{lcccc}
\hline & $\begin{array}{c}\text { No. of } \\
\text { live juniper } \\
\text { per plot }\end{array}$ & $\begin{array}{c}\text { No. of } \\
\text { dead juniper } \\
\text { per plot }\end{array}$ & $\begin{array}{c}\text { Height } \\
(\mathrm{m})\end{array}$ & $\begin{array}{c}\text { Diameter } \\
(\mathrm{m})\end{array}$ \\
\hline Fire treatment & $7.25 \mathrm{a}$ & $5.0 \mathrm{a}$ & $1.70 \mathrm{a}$ & $2.14 \mathrm{a}$ \\
Control & $22.75 \mathrm{~b}$ & $0.5 \mathrm{~b}$ & $1.35 \mathrm{~b}$ & $1.55 \mathrm{~b}$ \\
Probability value & $<0.001$ & $<0.001$ & 0.046 & 0.045 \\
\hline
\end{tabular}

not significantly different between treatment and control plots. To avoid disturbance effects on spread of fire, flashing was placed around the perimeter of the collectors after the first fire treatment. Along the bottom 3-m side, galvanized flashing hinged to plastic rain gutter and secured to allow about a $3-\mathrm{cm}$ opening was installed at ground level for collection of sediment. A hole in the end cap of the gutter allowed excess water to drain. Sediment transport occurred primarily with summer rains. This experimental design resulted in 4 treatment and 4 control sediment samplers at the West Mesa, and 8 treatment and 8 control sediment samplers at the Bernalillo Watershed ( 2 collectors per plot).

\section{Soil Microtopography}

Change in soil microtopography within each runoff collector was monitored using 2 soil erosion bridge locations established within the area of the runoff-sediment collectors prior to the burn ( 1 bridge location parallel to the top and 1 centered along the side of each collector; see White and Loftin [2000] for bridge description and image). The bridge used in this study has a center reference, which was created by placement of a nail with a receiving dimple beneath the middle hole of the bridge. The end pieces of rebar and the center nail create a 3-point line, which increases the accuracy over what would normally be a 2-point line (Shakesby 1993; Wilcox et al. 1994). Once the bridge is secured with a pin over the center nail, pins are inserted through holes in the bridge to the soil surface and the portion of each pin extending above the bar is measured. The 30-point profile reflects the soil-surface topography. The change in soil surface over time integrates both soil building and eroding processes, which include loss and gain of soil particles through wind and rain action.

\section{Soil Measurements and Analyses}

Soil samples were collected before and after each prescribed fire and annually at the end of the growing season. Surface-soil samples were collected under 3 cover types (shrub, grass, and bare soil) by taking 4-cm-wide cores to a depth of $20 \mathrm{~cm}$ at 2 locations each along three $60-\mathrm{m}$ belt transects inside the sampling area of each plot. The 6 soil cores of each cover type from each plot were composited into a single sample. This sample design produced 1 composite sample from each plot for bare, grass, and shrub cover types (sample size of 4 each for treatment and control).

Methods of soil handling and analyses are detailed in White and Loftin (2000). Potentially mineralizable N (PMN) was the amount of $\mathrm{N}$ (sum of $\mathrm{KCl}$-extractable $\mathrm{NH}_{4}-\mathrm{N}$ and $\mathrm{NO}_{3}-\mathrm{N}$ ) at the end of a 70 -day incubation at $20^{\circ} \mathrm{C}$ and $50 \%$ of waterholding capacity.

\section{Statistical Analyses}

Each site (Bernalillo Watershed and West Mesa) was analyzed separately. Unless otherwise indicated, a significance level of $P \leq 0.05$ was used. The West Mesa data were separated into pre- and post-wildfire periods for all analyses because there were no controls after the wildfire. The numbers of live and dead juniper were analyzed for fire treatment differences using the normal approximation of the binomial test. Height and crown diameter measures were analyzed using the normal approximation of the Wilcoxin 2-sample test (Zar 1984). For sediment transport and changes in soil microtopography, the sampling design allowed for the effects of fire treatment, collection dates, and their interaction to be tested with a 2factor analysis of variance (ANOVA) using the general linear model (GLM) procedure in SAS (SAS 1999). If significant effects of either factor or their interaction were found in the 2factor ANOVA, the effects of fire treatment were determined by analyzing each collection data by the ANOVA GLM procedure followed by the Duncan's procedure to identity when treatment means were significantly different. A similar procedure was used to determine which collection dates were significantly different.

The sampling design for vegetation cover and soils analyses included the additional factor of cover type (cover of grass or shrub; grass, shrub, or bare soil for PMN). Initial analyses of these data were performed by a 3-factor ANOVA using the GLM procedure to determine the effects of fire treatment, collection date, cover type, and their separate interaction factors. When significant effects of cover type were found, each cover type was analyzed separately to determine the effects of fire treatment and collection date using the ANOVA GLM procedure followed by Duncan's procedure to determine which means were significantly different. Each collection was analyzed separately for treatment and cover type using a 2factor ANOVA with GLM procedures followed by Duncan's procedure to determine differences in means of the treatments and vegetation types. If a significant fire treatment effect was found within a collection date, the effect of cover type was identified using GLM followed by Duncan's procedure.

\section{RESULTS}

\section{Woody Perennial Inventory}

Woody perennial inventory performed in 2001 found significantly fewer live junipers on the treated plots relative to the control plots (Table 1). The fire treatments were most successful at killing and removing the smaller seedlings but were not successful at killing the larger trees, which resulted in larger average size (height and width) of live junipers remaining on the burned plots relative to the control plots.

\section{Percentage Cover}

Plant cover on the Bernalillo Watershed showed complex relationships with fire treatment, cover type, collection date, and all interaction factors were highly significant (Table 2). 
Table 2. Results of 3-factor ANOVA for the analysis of the main effects of the listed factors on percentage cover at the Bernalillo Watershed and at the West Mesa before and after wildfire. Treatments include control and burned; cover types include cover of shrubs or grass.

\begin{tabular}{|c|c|c|c|c|c|c|c|c|c|}
\hline \multirow[b]{2}{*}{ Factors } & \multicolumn{3}{|c|}{$\begin{array}{c}\text { Bernalillo } \\
\text { Watershed }\end{array}$} & \multicolumn{3}{|c|}{$\begin{array}{c}\text { West Mesa } \\
\text { before wildfire }\end{array}$} & \multicolumn{3}{|c|}{$\begin{array}{l}\text { West Mesa } \\
\text { after wildfire }\end{array}$} \\
\hline & $\overline{d f^{1}}$ & $F$-value & $P$-level $\left.\right|^{2}$ & $\mathrm{df}$ & $F$-value & $P$-level & $\mathrm{df}$ & $F$-value & $P$-level \\
\hline Treatment (T) & 1 & 50.89 & 0.0001 & & 47.1 & 0.0001 & 1 & 7.66 & 0.0088 \\
\hline Cover type (cover) & 1 & 974 & 0.0001 & 1 & 1178 & 0.0001 & 1 & 920 & 0.0001 \\
\hline Collections (coll) & 10 & 21.8 & 0.0001 & & 43.3 & 0.0001 & 2 & 8.7 & 0.0008 \\
\hline \multicolumn{10}{|l|}{$\mathrm{T} \times$ cover } \\
\hline Interaction & 1 & 26.69 & 0.0001 & 1 & 0.001 & 0.98 & 1 & 9.28 & 0.0043 \\
\hline \multicolumn{10}{|l|}{$\mathrm{T} \times$ coll } \\
\hline Interaction & 10 & 6.309 & 0.0001 & 5 & 9.73 & 0.0001 & 2 & 0.074 & 0.92 \\
\hline \multicolumn{10}{|l|}{ Cover $\times$ coll } \\
\hline Interaction & 10 & 15.97 & 0.0001 & 5 & 34.4 & 0.0001 & 2 & 3.88 & 0.0295 \\
\hline \multicolumn{10}{|l|}{$\mathrm{T} \times$ cover $\times$} \\
\hline coll Interaction & 10 & 3.08 & 0.0017 & 5 & 6.51 & 0.0001 & 2 & 0.38 & 0.68 \\
\hline Error & 111 & & & 72 & & & 36 & & \\
\hline
\end{tabular}

Degrees of freedom.

${ }^{2}$ Probability level.

Grasses had significantly greater cover than shrubs (Fig. 2a), which accounted for cover type being the major factor in this analysis (Table 2). For the individual cover types, grass cover showed highly significant $(P<0.01)$ effects of fire treatment, collection date, and their interaction, whereas only collection date was significant for shrub cover (data not shown). Although total grass cover on the fire plots was never greater than cover on the controls, the burned plots showed significantly greater net increases in total grass cover during the 2 years following both fire treatments (mean net increase of $24.6 \%$ vs. $12.1 \%$ from 1996 to preburn 1998 and of $28.1 \%$ vs. $9.3 \%$ from 1998 postburn through 1999 in burned vs. control plots, respectively; $P<0.01$; Fig. 2a).

For the West Mesa before the wildfire, all factors except the treatment-by-cover type interaction were highly significant for plant cover (Table 2), indicating that complex interactions were occurring in plant cover up to that time. Fire treatment, collection date, and their interaction were significant factors for the cover of both grass and shrub, with declines in both cover types after the fire relative to the control, an increase in cover during wet periods, and a decline in cover during or shortly after drought periods (Fig. 2b). The burned plots showed significantly greater net increase in total grass cover during the 2 years following the fire treatment (mean net increase of 29.0 vs. 9.3 from 1996 through 1997 in burned vs. control plots, respectively; $P<0.01$; Fig. 2 b).

After the wildfire on the West Mesa, plant cover showed significant effects of fire treatment (grass cover on once-burned plots lower than grass cover on twice-burned), cover type (grass higher than shrub), collection date, the treatment-by-cover type interaction, and the cover type-by-collection date interaction (Table 2, Fig. 2b).

\section{Sediment Transport}

Factors that had significant effects on sediment transport at the Bernalillo Watershed were fire treatment $(P=0.0003)$, collec-
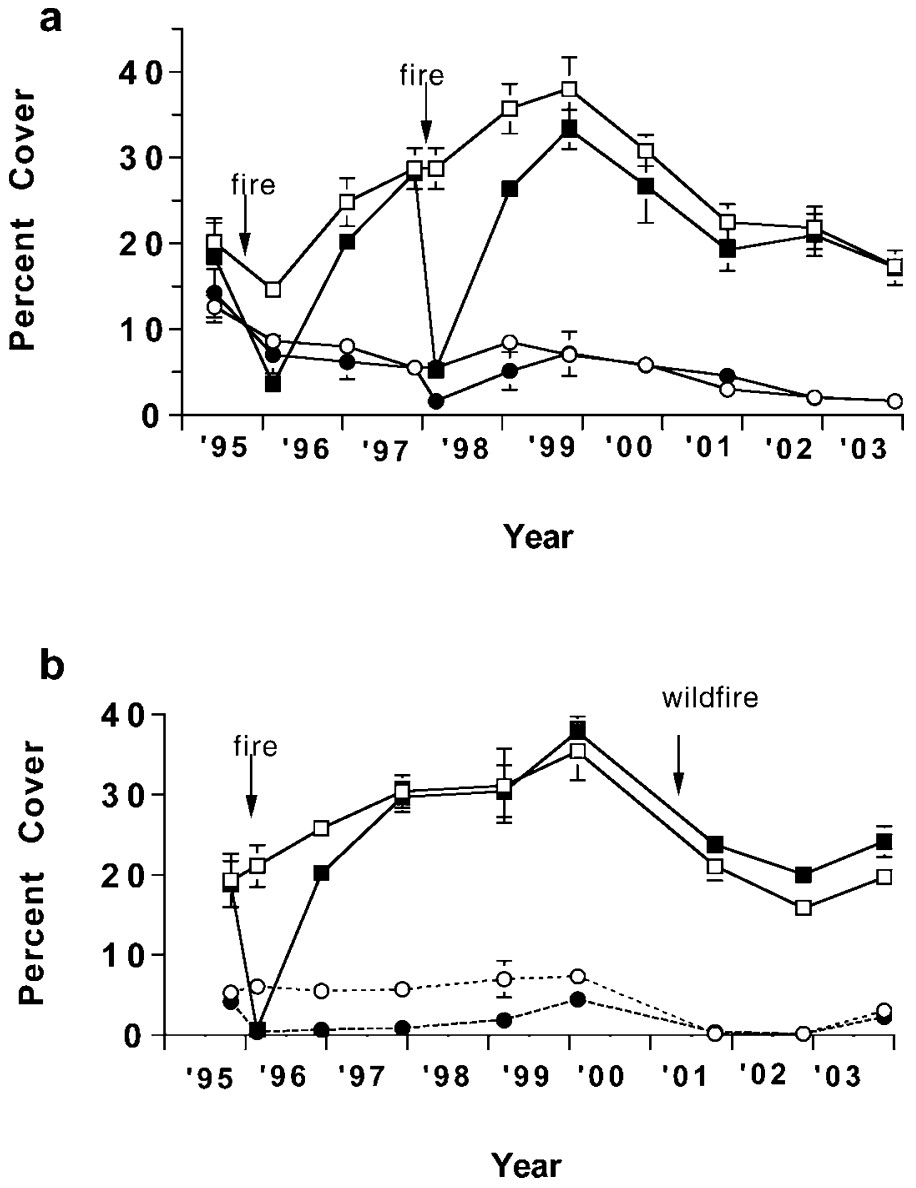

Figure 2. Percent cover (open symbols, control; filled symbols, fire treatment; mean \pm standard error) by shrubs (circles) and grass (squares) on the Bernalillo Watershed (a) and the West Mesa (b). Connecting lines are provided to aid in viewing patterns over time. Fire treatments (including wildfire) are indicated by arrows.

tion dates $(P=0.0001)$, and their interaction $(P=0.04)$. The fire treatments significantly increased sediment transport for about a year (Fig. 3a). The significant collection date effect is due to greater sediment transport during or shortly following drought periods of 1995 and 2002 (sediment in Fig. 3a, drought in Fig. 1). The significant treatment-by-collection interaction may reflect the change due to treatment followed by the return to control levels in later collections. We acknowledge that our interpretation of interaction factors may be subjective, especially if the interaction of more than 2 factors is involved.

At the West Mesa before the wildfire, fire treatment $(P=0.019)$, collection date $(P=0.0001)$, and their interaction $(P=0.038)$ were significant factors for sediment transport, which was higher relative to the controls after the fire treatment and higher during and after the 1995-1996 drought period relative to the wetter periods (Fig. 3b). After the wildfire, sediment transport was slightly higher from the once-burned plots relative to the twice-burned plots $(P=0.063)$, with no significant effect of collection date or treatment-by-collection interaction (Fig. 3b). However, the postwildfire sediment production must show some influence of the drought conditions, as shown by the rise in sediment from the Bernalillo Watershed at the same period (Figs. $3 a$ and $3 b$ ). 

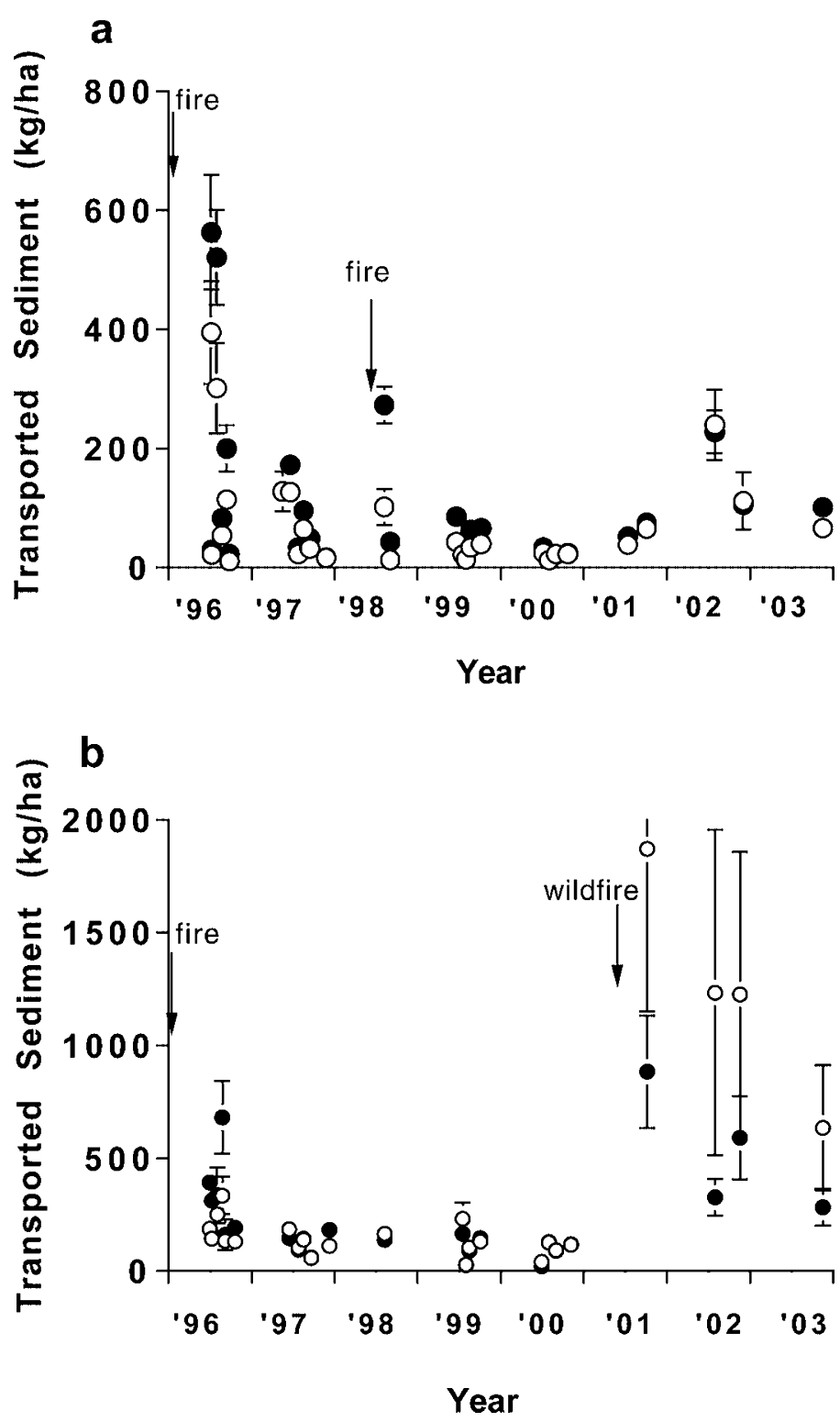

Figure 3. Transported sediment from the runoff plots at the Bernalillo Watershed (a) and the West Mesa (b). Each pair of circles represents 1 collection (open, control; filled, fire treatment; mean \pm standard error). Fire treatments are indicated by arrows. For some collections, the control circle may hide the treatment circle.

\section{Soil Microtopography}

Soil microtopography at the Bernalillo Watershed showed significant effects of fire treatment $(P=0.0001)$ and collection date $(P=0.012)$, with a nonsignificant interaction factor. The treatments resulted in greater lowering of the soil elevation relative to the controls (Fig. 4a). Greater loss of soil elevation (erosion or soil compaction) occurred during or after drought periods on all plots, accounting for the significant collection effect. Before the wildfire at the West Mesa, soil microtopography showed a similar pattern with significant fire treatment $(P=0.0001)$, collection date $(P=0.0001)$, and their interaction $(P=0.04)$ factors, and a net decline in burned plots relative to control after the 1996 fire (Fig. 4b). All plots showed a net increase in soil surface during the wet period, with the a

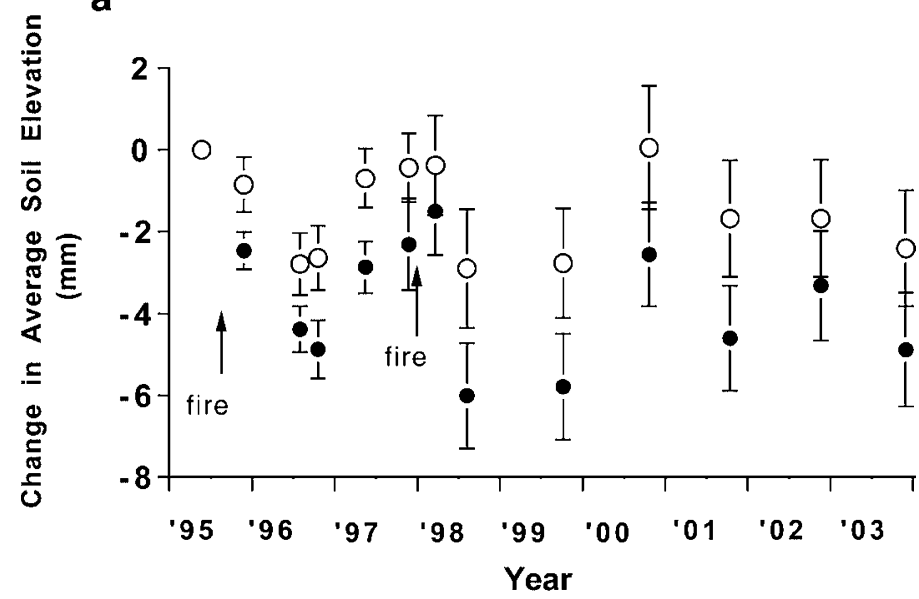

b

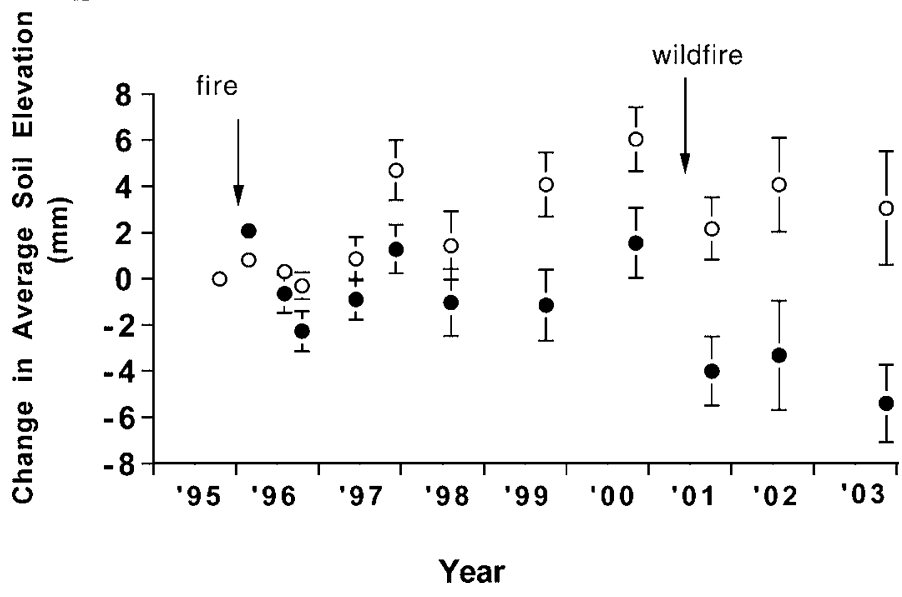

Figure 4. Change in soil microtopography relative to that at the beginning of the study (value of 0 ) at the Bernalillo Watershed (a) and the West Mesa (b). Each pair of circles represents 2 measurement period (open, control; filled, fire treatment; mean \pm standard error). Fire treatments are indicated by arrows.

control plots actually showing a net increase in soil surface elevation over the study period (Fig. 4b). After the wildfire, soil microtopography showed a highly significant fire treatment effect $(P=0.0001)$, with a greater decline in the twice-burned plots than in the once-burned plots (Fig. $4 \mathrm{~b}$ ).

\section{Potentially Mineralizable Nitrogen}

At the Bernalillo Watershed over the entire study period, PMN showed significant effects of collection date, cover type, and collection date-by-cover type interaction, with nonsignificant effects from the other factors, including treatment (Table 3 ). The significant collection date effect was due to the strong pattern of increased PMN during drought periods and lower PMN during wetter periods (Fig. 5a). The significant cover-type effects were due to the general pattern of soils beneath shrubs having the highest PMN, soils beneath grasses lower, and soils beneath bare areas much lower still on most collection dates (Fig. 5a). Collection date was highly significant $(P<0.0001)$ for PMN of soils beneath both grass and shrub, with fire not significant. However, there were 2 collections (1999 and 2000) that deviated 
Table 3. Results of 3-factor ANOVA for the analysis of the main effects of the listed factors on potentially mineralizable nitrogen at the Bernalillo Watershed and at the West Mesa before and after wildfire. Treatments include control and burned; cover types include soils from under shrubs, grass, or bare spots.

\begin{tabular}{|c|c|c|c|c|c|c|c|c|c|}
\hline \multirow[b]{2}{*}{ Factors } & \multicolumn{3}{|c|}{$\begin{array}{c}\text { Bernalillo } \\
\text { Watershed }\end{array}$} & \multicolumn{3}{|c|}{$\begin{array}{c}\text { West Mesa } \\
\text { before wildfire }\end{array}$} & \multicolumn{3}{|c|}{$\begin{array}{c}\text { West Mesa } \\
\text { after wildfire }\end{array}$} \\
\hline & $\mathrm{df}^{1}$ & $F$-value & $P$-level $\left.\right|^{2}$ & df & $F$-value & $P$-level & $\mathrm{df}$ & $F$-value & $P$-le \\
\hline Fire treatment $(\mathrm{T})$ & 1 & 0.30 & 0.58 & 1 & 1.63 & 0.2044 & 1 & 0.01 & 0.94 \\
\hline Cover type (cover) & 2 & 334.00 & 0.0001 & 2 & 194.39 & 0.0001 & 2 & 69.41 & 0.0001 \\
\hline Collections (coll) & 11 & 32.10 & 0.0001 & 5 & 29.43 & 0.0001 & 2 & 36.20 & 0.0001 \\
\hline \multicolumn{10}{|l|}{$\mathrm{T} \times$ cover } \\
\hline interaction & 2 & 0.18 & 0.91 & 2 & 1.47 & 0.2353 & 2 & 0.52 & 0.597 \\
\hline \multicolumn{10}{|l|}{$\mathrm{T} \times$ coll } \\
\hline interaction & 11 & 0.48 & 0.83 & 5 & 3.33 & 0.0078 & 2 & 2.15 & 0.126 \\
\hline \multicolumn{10}{|l|}{ Cover $x$} \\
\hline coll interaction & 22 & 3.35 & 0.0001 & 10 & 2.36 & 0.0145 & 4 & 3.05 & 0.0245 \\
\hline $\begin{array}{l}\mathrm{T} \times \text { cover } \times \\
\text { coll interaction }\end{array}$ & 22 & 0.50 & 0.97 & 10 & 0.75 & 0.67 & 4 & 3.28 & 0.01 \\
\hline Error & 180 & & & 107 & & & 54 & & \\
\hline
\end{tabular}

${ }^{1}$ Degrees of freedom.

${ }^{2}$ Probability level.

from this general pattern. In the 1999 collection, fire was a significant treatment (burned higher than control, $P<0.05$ ), while PMN under shrubs was not significantly higher than under grass. In the 2000 collection, neither fire nor cover type were significant factors. The lack of significant differences between grass and shrub in 2000 was due to the only occurrence when PMN under burned grass exceeded PMN under burned shrub, while the normal pattern was shown on the control plots with PMN under shrub exceeded PMN under grass (see Fig. 5a).

At the West Mesa before the wildfire, collection date, cover type, the interaction of fire treatment by collection date, and the cover type-by-collection interaction were significant factors for PMN (Table 3). Soils beneath shrubs had greater PMN than soils beneath grass, with the bare soil lowest (Fig. $5 \mathrm{~b}$ ). When the bare soil data were excluded, the only significant factor was cover type, with shrubs having higher PMN than grasses. After the wildfire, there were significant effects of collection date (a general increase over time consistent with drought effects), cover type (bare soils lower, but no statistical difference between grass and shrub), the interaction between collection date and cover type, and the 3-way interaction between treatment, cover type, and collection (Table 3; Fig. 5b). After the wildfire, PMN under grass exceeded PMN under shrub on the once-burned plots in 2002 and in the twice-burned plots in 2003.

\section{DISCUSSION}

Continued management of these grasslands with fire has generated mixed results. The 2 cool-season fires at the Bernalillo Watershed resulted in fewer small, live junipers and more dead junipers relative to the controls in 2001, which met the desired goal of a reduction of woody perennials for that particular species. Although the first fire at the Bernalillo Watershed did not significantly reduce total shrub cover (Fig.

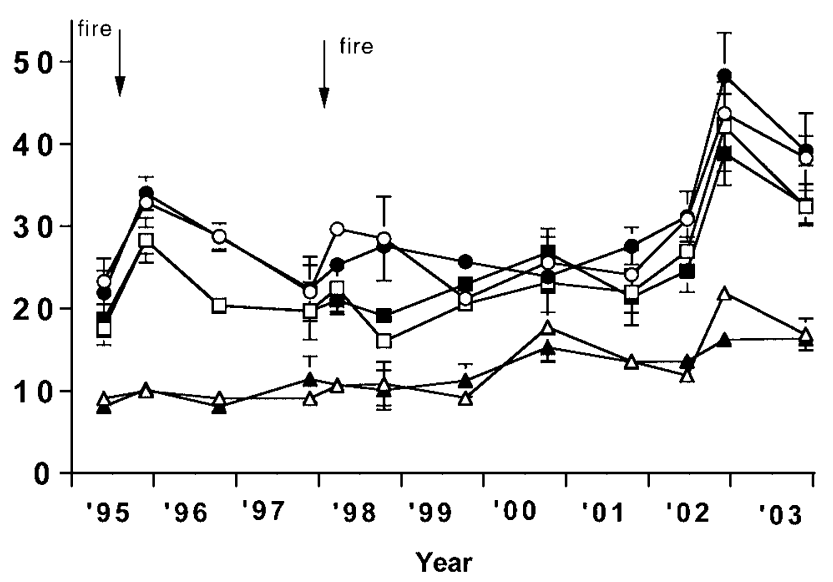

b

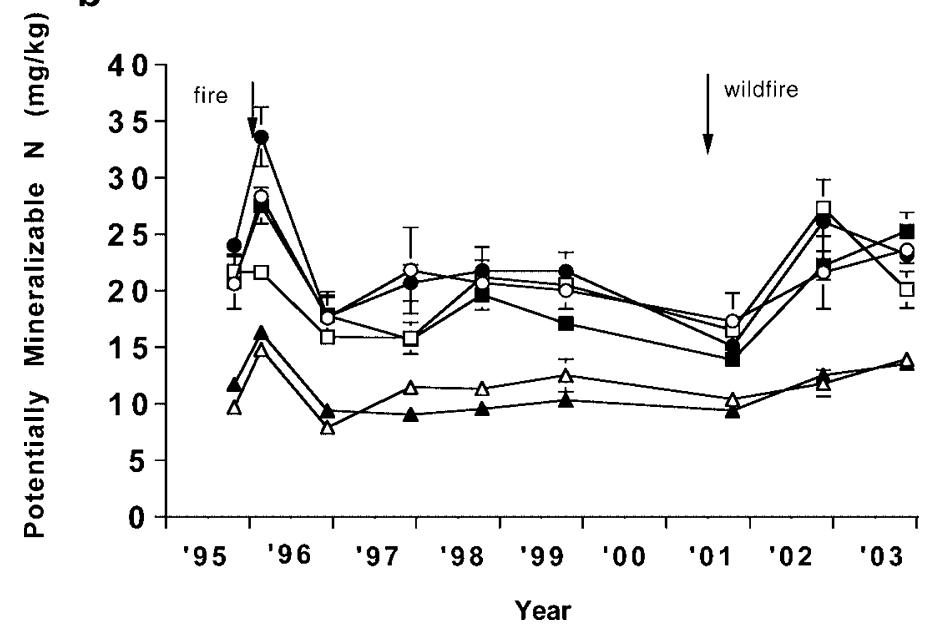

Figure 5. Changes in potentially mineralizable nitrogen (open symbols, control; filled symbols, fire treatment; mean \pm standard error) for soils beneath shrubs (circles), grass (squares), and bare areas (triangles) at the Bernalillo Watershed (a) and the West Mesa (b). Connecting lines are provided to aid in viewing patterns over time. Fire treatments are indicated by arrows.

2a, as reported in White and Loftin 2000), the second fire did reduce total shrub cover. Greater grass cover before the second fire $(28 \%)$ than in $1995(18.4 \%)$ increased fuel continuity and resulted in better fire coverage, which probably aided in total shrub reduction. This reduction was short-lived, however. Shrub cover of the burned plots equaled that of control plots by 2 growing seasons postfire. The subshrub broom snakeweed was largely responsible for this increase in total shrub cover. Broom snakeweed is capable of establishment in high numbers following favorable weather conditions and can be insensitive to control by fire (McDaniel et al. 1997).

The first fire on the West Mesa, a cool-season prescribed fire, was successful at reducing total shrub cover $(P<0.05)$, which lasted about 4 years. The second burn, which was a warmseason wildfire, was very effective at reducing total shrub cover (Fig. 2b), which was comprised of cover by broom snakeweed, fourwing saltbush, winterfat, and sand sage. Total shrub cover started to increase by 2003, which was mostly due to establishment of broom snakeweed and, to a lesser degree, 
resprouting of winterfat (C.S. White and R. Pendleton, personal observation). Thus, fire effects immediate reductions in shrub cover but may have limited ability for long-term control of certain species, particularly subshrubs, which would require repeat use of fire for long-term shrub control. These results are consistent with the suggested fire-return intervals of 5-10 years for control of shrub cover in semiarid grasslands (Wright 1980; Wright and Bailey 1982).

Our first hypothesis, that grasses should respond more rapidly than shrubs and achieve greater cover relative to shrubs, only held true for the West Mesa following the first fire (Fig. $2 \mathrm{~b})$. On the Bernalillo Watershed, however, the proportional increase in shrub cover was as rapid as grass cover after both fires (Fig. 2a). More important, although the net change in cover following the fire treatments was greater on the burned than on the control plots, fires did not stimulate an increase in total grass cover relative to the controls, which was the ultimate goal. In fact, fire caused significant short-duration decreases in cover because grass cover was the primary fuel combusted during the fires. The lack of expected aboveground grass response is being investigated through ongoing research that focuses on the quantity and quality of soil organic matter and the potential for increased belowground grass production.

Directly associated with the decrease in grass cover was the significant increase in sediment transport (Fig. 3a) and the decline in soil surface elevation (Fig. 4a). This result was consistent with our third hypothesis that erosion should increase following fire and return to that of the controls following recovery of vegetation cover, which occurred 2 years after the fire. Thus, management with prescribed fire can increase the potential for sediment production until replacement of the grass cover occurs. However, it appears that the potential for sediment production may decline with subsequent fires given that sediment production on the West Mesa tended to be lower on the plots burned twice than on the first-burned plots $(P=0.0633$, Fig. $3 \mathrm{~b})$, which may be the result of greater grass cover on the twice-burned plots.

A major factor contributing to the dynamics in all measurements was variation in the local climate and drought periods in particular. This study began at the onset of a severe drought period (PDI less than -2; Fig. 1), which was followed by abnormally high precipitation amounts over a 2-year period. The last 5 years included 3 periods of drought interrupted by 2 periods of normal or above-normal precipitation. All measurements showed distinct patterns that correspond to these drought-precipitation intervals. Plant cover decreased during drought and increased during wet periods (Fig. 2). Correspondingly, sediment transport increased in drought and decreased in wet periods (Fig. 3) and soil microtopography showed a net decline in elevation during drought and an increase during wet periods (Fig. 4). Similarly, imposed drought in a Montana grassland resulted in transport of sediment and associated nutrients in sufficient quantity to reduce water quality (Emmerich and Heitschmidt 2002). Even potential site fertility, as reflected in PMN values, responded with significantly increased PMN during drought and decreased PMN during wet periods (Fig. 5), a pattern shown in other semiarid grasslands (White et al. 2004).

Our second hypothesis, that fire would cause significant increases in PMN, has not occurred except immediately after the first fire on the West Mesa. The fire treatment did not immediately increase PMN at the Bernalillo Watershed after both fires, but PMN was greater in burned plots than in control plots in 1999, a year after the second fire (Fig. 5a). Also, measurements of PMN indicate that fire may have indirectly caused or allowed some fundamental, short-term changes in the pattern of soil fertility following the second fire at both sites. There was a highly significant overall relationship at both sites, with PMN in soils greatest under shrubs, lower under grass, and least in bare soil (Fig. 5). This pattern with resources sequestered in islands of fertility under plants, with shrubs having significantly greater resources than grasses, is well documented in semiarid regions (Schlesinger et al. 1990, 1996; Kieft et al. 1998; Bhark and Small 2003). The only periods when PMN under shrubs was not significantly greater than under grass occurred after the second cool-season fire at the Bernalillo Watershed and after the warm-season wildfire at the West Mesa (Fig. 5). After the growing season of 2000 at the Bernalillo Watershed, PMN under grass in the burned plots exceeded the values for shrubs in both the control and burned plots; the only time that PMN in soils under grass was higher than in soils under shrubs at this site (Fig. 5a).

The West Mesa had a significant fire effect with an increase in PMN on the burned plots relative to the control plots for the first collection after the cool-season fire (Fig. 5b). Consistent with the pattern at the Bernalillo Watershed, soil under shrubs had higher PMN than soils under grass before and following the first fire. The only major divergence from that pattern occurred after the warm-season wildfire, when there was no difference between the grass and shrub cover types for PMN. Furthermore, in 2002, the soils in the once-burned plots had higher PMN under grass than soils under shrubs, and in 2003, the twice-burned plots had higher PMN in soils under grass than under shrubs (Fig. 5b). Thus, there were short periods following fires at both sites where soil resources under shrubs were not greater than resources under grasses, which may indicate a departure from the current island-of-fertility paradigm.

Causes for changes in the pattern of resource availability following fire were not directly investigated; however, trends in our data suggest at least 2 interacting factors that may account for the observed changes. First, greater erosional loss of soil beneath shrubs relative to grass could occur after fire, removing accumulated resources from beneath shrubs, leaving relatively more resources beneath grasses and creating a more even resource distribution. Second, if fire stimulated a net increase in aboveground grass production relative to the unburned plots, as suggested by the rapid increase in total grass cover for 2 years following the fires, then a similar increase in belowground production of readily decomposable organic detritus may account for the observed increase in PMN under grass 2 or 3 growing seasons after the fires. Further stimulation of belowground grass production should increase soil organic matter and build soil fertility.

\section{MANAGEMENT IMPLICATIONS}

In conclusion, fire in these grasslands has allowed for shortterm changes in soil fertility relationships that appeared well established in the absence of fire. Short periods of higher soil 
fertility under islands of grass relative to shrub islands suggest that fire creates opportunities for changes in the distribution of soil resources. Fire may stimulate belowground grass production, eventually building greater soil fertility and an increase in grass cover, and eventually lowering soil erosion. However, any long-term benefits from potential increases in soilbuilding processes would have to be balanced against the short-term loss of resources after fire that are associated with the loss of cover, increased short-term erosion, and potential sediment contribution to streams.

\section{ACKNOWLEDGMENTS}

The authors are grateful to an associate editor and 2 anonymous reviewers for their excellent suggestions and detailed work that greatly improved this article. Also, we are grateful for all the people who helped in this research: Sam Loftin, Mike Means, David Hawksworth, Manny Gonzales, Richard Gatewood, Ruben Leal, Randi Paris, John Craig, Chris Thomas, Steve Hofstad, Robyn Phillips, Ray Romero, Sandra and Christopher White, Shawn West, and all those who actually performed the prescribed burns (Cibola National Forest-Sandia Ranger District, New Mexico State Forestry, Placitas Fire Brigade, Sandoval County Fire Department, and Albuquerque Fire Dept).

\section{LITERATURE CITED}

Bhark, E. W., and E. E. Small. 2003. Association between plant canopies and the spatial patterns of infiltration in shrubland and grassland of the Chihuahuan desert, New Mexico. Ecosystems 6:185-196.

Briggs, J. M., AND D. J. Gibson. 1992. Effect of fire on tree spatial patterns in a tallgrass prairie landscape. Bulletin of the Torrey Botanical Club 199: 300-307.

Brooks, K. N., P. F. Folliott, H. M. Gregersen, and J. L. Thames. 1991. Hydrology and the management of watersheds. Ames, IA: Iowa State University Press. $502 \mathrm{p}$.

Brown, D. E. [ED.]. 1982. Biotic communities of the American Southwest-United States and Mexico. Desert Plants 4:1-4.

Buffington, L. C., and C. H. Herbel. 1965. Vegetation changes on a semidesert grassland range from 1858 to 1963. Ecological Monographs 35:139-164.

Соoк, K. 1995. Prescribed fires benefit Carson National Forest. New Mexico Wildlife 1995(July/August):10-13.

DeBano, L. F., D. G. Neary, and P. F. Foluiott. 1998. Fire's effects on ecosystems. New York, NY: John Wiley \& Sons. 333 p.

Emmerich, W. E., and R. K. Heitschmidt. 2002. Drought and grazing: II. Effects on runoff and water quality. Journal of Range Management 55:229-234.

Frederickson, E., K. M. Havstad, R. Estell, and P. Hyder. 1998. Perspectives on desertification: south-western United States. Journal of Arid Environments 39:191-207.

Gottfried, G. J., T. W. Swetnam, C. D. Allen, J. L. Betancourt, and A. L. ChungMacCoubreY. 1995. Pinyon-juniper woodlands. In: D. M. Finch and J. A. Tainter [EDS.]. Ecology, diversity and sustainability of the middle Rio Grande basin. Fort Collins, CO: USDA Forest Service. RMGTR-268. p 95-132.

Grover, H. D., AND H. B. Musick. 1990. Shrubland encroachment in southern New
Mexico, U.S.A.: an analysis of desertification processes in the American southwest. Climate Change 17:305-330.

Kieft, T. L., C. S. White, S. R. Loftin, R. Aguilar, J. A. Craig, and D. A. Skaar. 1998. Temporal dynamics in soil carbon and nitrogen resources at a grasslandshrubland ecotone. Ecology 79:671-683.

McDaniel, K. C., C. R. Hart, and D. B. Carroll. 1997. Broom snakeweed control with fire on New Mexico blue grama rangeland. Journal of Range Management 50(6):652-659.

MitcheLL, J. D. 1978. The American Indian: a fire ecologist. American Indian Culture Research Journal 2:26-31.

[NNWQCC] New MeXico Water Quality Control Commission. 1994. Water quality and water pollution control in New Mexico. A report prepared for submission to the Congress of the United States by the State of New Mexico pursuant to Section 305(b) of the Federal Water Pollution Control Act, Sept. 1994. Santa Fe, NM.

O'Dea, M. E., and D. P. Guertin. 2003. Prescribed fire effects on erosion parameters in a perennial grassland. Journal of Range Management 56: 27-32.

Palmer, W. C. 1965. Meteorological drought. Research paper 45. Washington, DC: U.S. Weather Bureau, NOAA Library and Information Services Division.

PASE, C. P. 1981. Community structure analysis-a rapid, effective range condition estimator for semi-arid lands. In: H. G. Lund, M. Caballero, R. H. Hamre, R. S. Driscoll, and W. Bonner [TECH. COORDS.]. Arid land resources inventories: developing cost-efficient methods. Washington, DC: USDA Forest Service. GTR W0-28. p 425-430.

SAS. 1999. SAS/STAT® Version 8. Cary, NC: SAS Institute Inc.

Schlesinger, W. H., A. D. Abrahams, A. J. Parsons, and J. Wainwright. 1999. Nutrient losses in runoff from grassland and shrubland habitats in Southern New Mexico: I. Rainfall simulation experiments. Biogeochemistry 45:21-34.

Schlesinger, W. H., J. A. Raikes, A. E. Hartley, and A. F. Cross. 1996. On the spatial pattern of soil nutrients in desert ecosystems. Ecology 77:364-374.

Schlesinger, W. H., J. F. Reynolds, G. L. Cunningham, L. F. Huenneke, W. M. Jarrell, R. A. VIRGINIA, AND W. G. Whitford. 1990. Biological feedbacks in global desertification. Science 247:1043-1048.

Shakesby, R. A. 1993. The soil erosion bridge: a device for micro-profiling soil surfaces. Earth Surface Processes Landforms 18:823-827.

[USDA] US Department of Agriculture. 1982. Range analysis handbook. Section 4.63. Ogden, UT: Region 4, USDA Forest Service. $46 \mathrm{p}$.

White, C. S., AND S. R. Loftin. 2000. Response of 2 semiarid grasslands to coolseason prescribed fire. Journal of Range Management 53:52-61.

White, C. S., D. I. Moore, AND J. A. Cralg. 2004. Regional-scale drought increases potential soil fertility in semiarid grasslands. Biology and Fertility of Soils 40:73-78.

WiLCoX, B. P. 1994. Runoff and erosion in intercanopy zones of pinyon-juniper woodlands. Journal of Range Management 47:285-295.

Wilcox, B. P., J. Pitlick, AND C. D. Allen. 1994. Frijolito watershed: integrated investigations of a rapidly eroding pinyon-juniper hillslope. Semiarid Hydrology Conference; 1-3 November 1994; Tucson, AZ. LA-UR 94-3833.

WRIGHT, H. A. 1980. The role and use of fire in the semidesert grass-shrub type. GTR INT-85. Ogden, UT: USDA Forest Service. $24 \mathrm{p}$.

Wright, H. A., AND A. W. Balley. 1982. Fire ecology: United States and Canada. New York, NY: John Wiley \& Sons, Inc.

Zar, J. H. 1984. Biostatistical analysis. 2nd Ed. Englewood Cliffs, NJ: PrenticeHall, Inc. 718 p. 